\title{
JUAL BELI BARANG DENGAN CARA IFSAD DI KELURAHAN WEK-I KECAMATAN PADANGSIDIMPUAN UTARA
}

\author{
Elisa Rizky Siregar \& Zul Anwar Ajim Harahap \\ IAIN Padangsidimpuan \\ zulanwar.ajimhrp@gmail.com
}

\begin{abstract}
The problem in this research is how the practice of buying and selling goods by means of IFSAD Wek-I Subdistrict Padangsidimpuan North District, and how Fiqh Muamalah reviews about buying and selling goods by Ifsad in Wek-I Subdistrict, Padangsidimpuan Utara District. The purpose of this study was to find out the practice of buying and selling goods by means of Ifsad Wek-I Subdistrict, Padangsidimpuan North District, and to find out about Fiqh Muamalah review about the sale and purchase of goods by Ifsad in Wek-I Subdistrict, Padangsidimpuan Utara District. This type of research is qualitative research, namely the research process to produce data in the form of explanations, both written and unwritten with the people studied. The researchers examined were 16 sellers and 7 buyers. The results of this study obtained ifsad sale and purchase of goods carried out by some traders in WekI Sub-District, North Padangsidimpuan District, namely if the traders sell by weighing and wrapping the cooking oil and granulated sugar with each plastic-sized benchmark. Like wrapping each cooking oil in a plastic measuring $1 / 4 \mathrm{~kg}$. When the buyer comes the seller immediately gives the goods that have been wrapped in advance without any weighing in front of the buyer so as to raise doubts about the buyer. Each package is usually not in accordance with the scales, if the buyer returns to the item purchased because the scale is less, the seller does not want to give less than the purchased, because the seller says that the scales are sold accordingly, while the stall is not indicated when the buyer arrives. An Overview of Muamalah Fiqh on the sale and purchase by Ifsad in Wek-I Subdistrict, Padangsidimpuan Utara Subdistrict has not been in accordance with the provisions contained in one of the conditions of the sale and purchase contract that is known to be known, the amount, the size, or the other sizes.
\end{abstract}

Key Words: Buying; and Selling; Ifsad, and Goods.

\begin{abstract}
Abstrak
Masalah dalam penelitian ini adalah bagaimana praktek jual beli barang dengan cara ifsad Kelurahan Wek-I Kecamatan Padangsidimpuan Utara, dan bagaimana tinjauan Fiqh Muamalah tentang jual beli barang dengan cara ifsad di Kelurahan Wek-I Kecamatan Padangsidimpuan Utara. Tujuan penelitian ini adalah untuk mengetahui praktek jual beli barang dengan cara ifsad Kelurahan Wek-I Kecamatan Padangsidimpuan Utara, dan untuk mengetahui tinjauan Fiqh Muamalah tentang jual beli barang dengan cara ifsad di Kelurahan Wek-I Kecamatan Padangsidimpuan Utara. Jenis penelitian ini adalah penelitian kualitatif yaitu proses penelitian untuk
\end{abstract}


menghasilkan data berupa penjelasan, baik tertulis maupun tidak tertulis dengan orang-orang yang diteliti. Adapun yang diteliti oleh peneliti adalah 16 penjual dan 7 pembeli. Hasil penelitian ini diperoleh jual beli barang ifsad yang dilakukan sebagian pedagang di Kelurahan Wek-I Kecamatan Padangsidimpuan Utara yaitu apabila pedagang menjual dengan cara menimbang dan membungkus terlebih dahulu minyak goreng dan gula pasir tersebut dengan masing-masing yang berukuran dengan patokan plastik. Seperti membungkus masing-masing minyak goreng dalam plastik yang berukuran $1 / 4 \mathrm{~kg}$. Disaat pembeli datang penjual langsung memberi barang yang sudah dibungkus terlebih dahulu tanpa adanya penimbangan didepan pembeli sehingga menimbulkan keraguan terhadap pembeli. Setiap bungkusan biasanya tidak sesuai dengan timbangannya, apabila pembeli kembali kewarung barang yang telah dibeli karena timbangannya kurang, penjual tidak mau memberi kurang dari yang dibeli tersebut, karena penjual mengatakan bahwa timbangan yang dijual sesuai, sedangkan di warung tidak ditunjukkan timbangan saat pembeli datang. Tinjauan Figh Muamalah terhadap jual beli dengan cara ifsad di Kelurahan Wek-I Kecamatan Padangsidimpuan Utara belum sesuai dengan ketentuan yang terdapat pada salah satu syarat-syarat benda yang menjadi objek akad jual beli yaitu diketahui (dilihat) barang yang diperjual belikan harus diketahui banyaknya, beratnya, takarannya, atau ukuran-ukuran yang lainnya.

Kata Kunci: jual beli; ifsad; dan barang.

\section{PENDAHULUAN}

Jual beli fasid ialah yang memenuhi salah satu syarat dan rukun sehingga jual beli jadi rusak. Penjualan yang tidak dilakukan seperti ketetapan syara' batal sama dengan fasad, dan fasid sama dengan batil (dalam segenap urusan). ${ }^{1}$ Apabila kerusakan pada jual beli itu menyangkut harga barang dan boleh diperbaiki maka jual beli itu dinamakan fasid. Ifsad/ perusakan adalah pengurangan kualitas nilai suatu barang. Ketika membeli suatu barang maka kita mengharapkan takaran yang sesuai dengan yang kita inginkan, sebaliknya di saat kita menjual suatu barang maka kita sebaiknya memberi takaran yang sesuai kepada pembeli, agar tidak ada ada unsur gharar atau penipuan, pada intinya ketika kita tidak ingin rugi maka jangan rugikan orang lain dengan menipunya.

Dalam Kompilasi Hukum Ekonomi Syariah pada pasal 77 mengatakan bahwa jual beli dapat dilakukan terhadap:

a. Barang yang terukur menurut porsi, jumlah, berat, atau panjang baik berupa satuan atau keseluruhan.

${ }^{1}$ Teungku Muhammad Hasbi Ash Shiddieqy, Pengantar Hukum Islam, (Semarang: PT. Pustaka Rizki Putra, 1987), hlm. 484. 
b. barang yang diukur atau ditimbang sesuai jumlah yang telah ditentukan, sekalipun kapasitas dari takaran dan timbangan tidak diketahui.

c. satuan komponen dari barang yang sudah dipisahkan dari komponen yang lain yang telah dijual.

Pada kenyataannya fakta lapangan bahwa pedagang yang di Kelurahan wek-I Kecamatan Padangsidimpuan Utara ada yang melakukan jual beli dengan cara ifsad seperti tidak mencantumkan ukuran dan beratnya akan tetapi pedagang tersebut ada yang membungkus barang terlebih dahulu sebelum adanya pembeli dan disaat pembeli datang untuk membeli, penjual langsung memberi barang tersebut tanpa memberi keterangan yang jelas kepada pembeli.

Seorang pedagang yang berada di Kelurahan wek-I Kecamatan Padangsidimpuan Utara ini pada umumnya tidak menjual barang-barang yang menggunakan timbangan seperti menjual bawang, cabe dan lain lain, akan tetapi pedagang tersebut lebih cenderung menjual makanan bungkusan ataupun snack pabrik. Dan pedagang tersebut juga menjual minyak goreng dan gula, akan tetapi pedagang tersebut menjual dengan cara membungkus terlebih dahulu sebelum pembeli datang, misalnya gula pasir sebanyak $1 / 2$ kilo, penjual membungkus banyak gula pasir masing-masing dengan menggunakan plastik dengan ukuran $1 / 2$ kilo, akan tetapi di setiap plastik gula pasir tersebut yang dimasukkan ada yang sesuai dan ada yang tidak sesuai. Ketika pembeli datang untuk membeli gula pasir sebanyak $1 / 2$ kilo maka penjual langsung memberi gula pasir yang sudah dibungkus tersebut kepada pembeli tanpa menimbangnya di depan pembeli, karena penjual membungkus gula pasir tersebut dengan plastik $1 / 2$ kilo maka otomatis pembeli akan percaya bahwa gula pasir tersebut benarbenar $1 / 2$ kilo, namun penjual memanfaatkan kepercayaan pembeli.

Cara seperti ini di satu sisi merugikan pembeli dan di sisi lain dapat menguntungkan penjual. Penjual tidak memiliki timbangan sedangkan penjual menjual barang yang harus ditimbang, akan tetapi hanya mengandalkan plastik yang sesuai ataupun yang seharusnya tanpa menimbangnya apakah sudah sesuai ataupun tidak. Dari transaksi tersebut konsumen merasa ragu namun tidak dapat meminta penjelasan yang lebih lanjut karena tidak ada timbangan yang ditunjukkan di warung tersebut, dan di rumah wargapun tidak 
236 | TAZKIR: Jurnal Penelitian Ilmu-ilmu Sosial dan Keislaman

Vol. 04 No. 2 Desember 2018

mempunyai timbangan, karena barang tersebut sangat dibutuhkan dan konsumen langsung membeli saja.

Masalah-masalah disini perlu diperhatikan di dalam Figh Muamalah yang mengatakan bahwa barang yang diperjual-belikan harus dapat diketahui banyaknya, beratnya, takarannya, atau ukuran-ukuran yang lainnya, maka tidaklah sah jual beli yang menimbulkan keraguan salah satu pihak. Jadi dari beberapa permasalahan yang ada mengenai jual beli barang dengan cara ifsad maka peneliti tertarik untuk meneliti dengan judul: "Jual Beli Barang Dengan Cara Ifsad di Kelurahan Wek-I Kecamatan Padangsidimpuan Utara".

Berdasarkan latar belakang masalah di atas, maka tujuan dari penelitian ini adalah untuk mengetahui praktek jual beli barang dengan cara ifsad di Kelurahan wek-I Kecamatan Padangsidimpuan Utara dan mengetahui bagaimana tinjauan fiqh muamalah terhadap jual beli barang dengan cara ifsad di Kelurahan wek-I Kecamatan Padangsidimpuan Utara.

\section{KAJIAN TEORITIS}

Perdagangan atau jual beli menurut bahasa berarti al Ba'i, al-tijarah, dan almubadalah. ${ }^{2}$ Menurut istilah (terminologi) yang dimaksud dengan jual beli adalah sebagai berikut: ${ }^{3}$

1. Menukar barang dengan barang atau barang dengan uang dengan jala melepaskan hak milik dari yang satu ke yang lain atas dasar saling merelakan.

2. Pemilikan harta benda dengan jalan tukar menukar yang sesuai dengan aturan syara.

3. Saling tukar harta, saling menerima, dapat dikelola (tasharruf) dngan ijab dan qabul, dengan cara yang sesuai dengan syara.

4. Tukar menukar benda dengan benda lain dengan benda yang khusus (diperbolehkan).

5. Penukaran benda dengan benda dengan jalan saling merelakan atau memindahkan hak milik dengan yang ada penggantinya dengan cara yang diperbolehkan.

${ }^{2}$ Hendi Suhendi, Fiqh Muamalah, Jakarta: PT. Rajagrafindo Persada, 2014. hlm. 6768.

${ }^{3}$ Hendi Suhendi, Figh Muamalah..., hlm. 67-68. 
6. Aqad yang tegak atas dasar penukaran harta dengan harta, maka jadilah penukaran hak milik secara tetap.

Jual beli merupakan sebuah transaksi atas suatu manfaat.Dan jual beli ada dua macam, yaitu jual beli barang yang bersifat umum dan jual beli barang yang bersifat khusus. ${ }^{4}$

Jual beli dalam arti umum ialah suatu perikatan tukar menukar sesuatu yang bukan kemanfaatan dan kenikmatan, perikatan adalah akad yang mengikat dua belah pihak, tukar menukar yaitu salah satu pihak menyerahkan ganti penukaran atas sesuatu yang ditukarkan oleh pihak lain. Dan sesuatu yang bukan manfaat ialah bahwa benda yang ditukarkan adalah berbentuk, ia berfungsi sebagai obek penjualan, jadi bukan manfaatnya atau bukan hasilnya.

Jual beli dalam arti khusus adalah ikatan tukar menukar sesuatu yang bukan kemanfaatan dan bukan pula kelezatan yang mempunyai daya tarik, penukarannya bukan mas dan bukan pula perak, bendanya dapat direalisir dan ada seketika (tidak ditangguhkan), tidak merupakan hutang baik barang itu ada di hadapan pembeli maupun tidak, barang yang sudah diketahui sifat-sifatnya atau sudah diketahui terlebih dahulu.

Dari beberapa defenisi diatas dapat dipahami bahwa inti jual beli ialah suatu perjanjian tukar menukar benda atau benda yang mempunyai nilai secara sukarela diantara kedua belah pihak, yang satu menerima benda-benda dan pihak lain menerimanya sesuai dengan perjanjian atau ketentuan yang dibenarkan syara dan disepakat.

\section{Dasar Hukum Jual Beli}

Didalam Islam jual beli sudah jelas diakui, khususnya dalam alquran juga banyak pembahasan tentang jual beli. Hal ini konsep yang sudah diatur dalam hukum islam. Karena itu segala peraturan yang ada dalam hukum islam, yang menjadi dasar hukum jual beli adalah :

a. Al-qur'an

1. Firman Allah SWT surat Al-Mutaffifin: $1-6^{5}$

${ }^{4}$ Hendi Suhendi, Fiqh Muamalah..., hlm. 67-68.

5Departemen Agama, Al-Quran dan Terjemahannya, (Jakarta: Wisma Haji Tugu, 2007), hlm. 278. 
238 | TAZKIR: Jurnal Penelitian Ilmu-ilmu Sosial dan Keislaman

Vol. 04 No. 2 Desember 2018

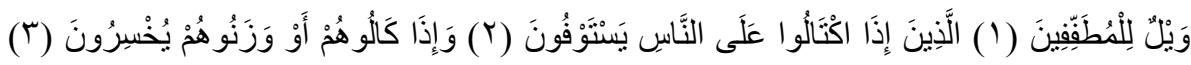

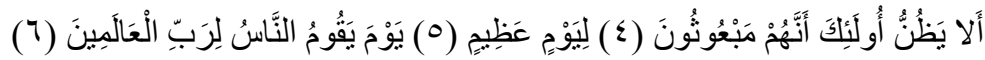

Artinya: kecelakaan besarlah bagi orang orang yang curang, yaitu orang orang yang apabila menerima takaran dari orang lain mereka minta penuhi, dan apabila mereka menakar atau menimbang untuk orang lain mereka mengurangi, tidaklah orang orang itu menyangka bahwa sesungguhnya mereka akan dibangkitkan pada suatu hari yang besar, yaitu hari ketika manusia berdiri menghadap tuhan semesta alam?".

2. Firman Allah SWT surat Al-Baqarah: $254^{6}$

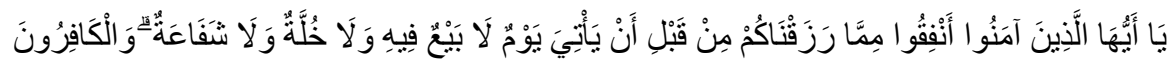

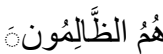

Artinya: hai orang orang beriman, belanjakanlah (di jalan Allah) sebagian dari rejeki yang telah kami berikan kepadamu sebelum datang hari yang pada hari itu tidak ada lagi jual beli dan tidak ada lagi syafa'at. Dan orang orang itulah orang orang yang zalim".

3. Firman Allah surat An-nisa: 29.7

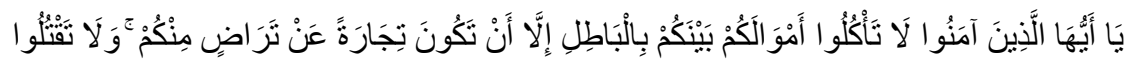

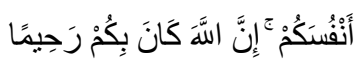

Artinya: hai orang orang yang beriman, janganlah kamu saling memakan harta sesamamu dengan jalan yang batil, kecuali dengan jalan perniagaan yang berlaku dengan suka sama suka diantara kamu. Dan janganlah kamu membunuh dirimusesungguhnya Allah adalah maha penyayang padamu".

Berdasarkan beberapa nash Al-quran tersebut dapat dipahami bahwa jual beli dibenarkan dalam Islam namun harus sesuai dengan syariat Islam. Jual beli merupakan transaksi yang hampir setiap hari dilakukan oleh 
manusia, namun banyak orang yang menyalahgunakannya dengan memanfaatkannya dengan cara yang tidak sesuai dengan syariat islam. Seperti menipu dan mengharapkan riba. Dari nash Allah telah jelas menerangkan bahwa riba adalah perbuatan yang tidak boleh dilakukan karena akan menimbulkan kerugian bagi satu pihak. Dan Allah juga mengatakan bahwa mengambil harta orang lain itu adalah hak buruk kecuali engkau melakukannya dengan perniagaan atau jual beli yang sah. Dan di saat berjual beli hendaklah kita berhati hati dan jangan sampai melakukan perniagaan yang salah dengan cara penipuan sehingga menimbulkan riba di dalamnya.

\section{b. Hadits}

1. Dari Utsman r.a, ia berkata "Rasululloh Shallallahu 'alaihi Wasallam bersabda: ${ }^{8}$

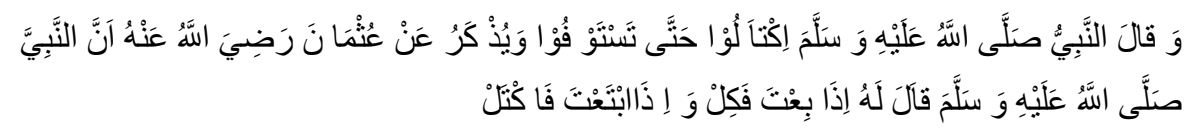

Artinya: Nabi SAW bersabda: Takarlah sehingga kalian memenuhinya.

Diceritakan dari Utsman r.a. bahasanya Nabi bersabda kepadanya "apabila kamu berjualan, maka takarlah, dan apabila engkau membeli makanan mintalah ditakar".

2. Dari Abdullah bin Umar r. $a^{9}$

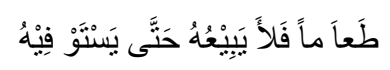

Artinya:Barang siapa yang membeli makanan, maka janganlah menjualnya sehingga dipenuhi takarannya".

\section{Rukun dan Syarat Sah Jual Beli}

\section{Akad (ijab kabul)}

Akad ialah ikatan kata antara penjual dan pembeli, jual beli belum dikatakan sah sebelum ijab kabul dilakukan, sebab ijab kabul menunjukkan kerelaan (keridhaan), pada dasarnya ijab kabul dilakukan dengan lisan, tapi

${ }^{8}$ Achmad sunarto dkk, Shahih Bukhari Jilid III, (Semarang: Asy-Syifa, 1993), hlm. 247.

\footnotetext{
9 Achmad sunarto dkk, Shahih Bukhari..., hlm. 248.
} 
240 | TAZKIR: Jurnal Penelitian Ilmu-ilmu Sosial dan Keislaman

Vol. 04 No. 2 Desember 2018

kalau tidak mungkin, seperti bisu atau yang lainnya, maka boleh ijab kabul dengan surat-menyurat yang mengandung arti ijab kabul ${ }^{10}$. Adanya kerelaan tidak dapat dilihat sebab kerelaan berhubungan dengan hati, oleh karena itu kerelaan dapat diketahui melalui tanda-tanda lahirnya, tanda yang jelas menunjukkan kerelaan adalah ijab dan kabul.

Syarat-syarat ijab kabul ialah:

a. Jangan ada yang memisahkan, janganlah pembeli diam saja setelah penjual menyatakan ijab dan sebaliknya.

b. Jangan diselangi dengan kata kata lain antara ijab dan kabul.

c. Beragama islam, syarat ini khusus untuk pembeli saja dalam benda benda tertentu, seperti seorang dilarang menjual hambanya yan beraama islam, sebab besar kemungkinan pembeli tersebut akan merendahkan abid yang beragama islam, sedangkan Allah melarang orang orang mukmin memberi jalan kepada orang kafir untuk merendahkan mukmin.

\section{Ma'kud alaih (obyek akad)}

Benda-benda dan barang yang diperjualbelikan mempunyai syarat-syarat yaitu: ${ }^{11}$

1. Suci dan mungkin untuk disucikan, maka tidak sah penjualan bendabenda najis seperti anjing, babi dan yang lainnya.

2. Memberi manfaat menurut Syara', maka dilarang jual beli benda-benda yang tidak boleh diambil manfaatnya menurut Syara', seperti menjual babi, kala, cicak dan lainnya.

3. Jangan ditaklikan, yaitu dikaitkan atau digantungkan kepada hal hal lain, seperti; jika ayahku pergi kujual motor ini kepadamu.

4. Tidak dibatasi waktunya, seperti perkataan kujual motor ini kepada kepada tuan selama satu tahun, maka penjualan tersebut tidak sah, sebab jual beli adalah salah satu sebab pemilikan secara penuh yang tidak dibatasi apapun kecuali ketentuan Syara'.

5. Dapat diserahkan secara cepat maupun lambat, tidaklah sah menjual binatang yang sudah lari dan tidak dapat ditangkap lagi, barang-barang yang sudah hilang atau barang yang sulit diperoleh kembali karena

${ }^{10}$ Hendi Suhendi, Figh Muamalah..., hlm. 77-85.

${ }^{11}$ Hendi Suhendi, Fiqh Muamalah..., hlm. 77-85. 
samar, seperti seekor ikan jatuh ke kolam, maka tidak diketahui dengan pasti ikan tersebut, sebab dalam kolam tersebut dapat ikan kan yang sama.

6. Milik sendiri, tidaklah sah menjual barang orang lain dengan tidak seizin pemiliknya atau barang barang yang baru akan jadi miliknya.

7. Diketahui (dilihat), barang yang diperjualbelikan harus dapat diketahui banyaknya, beratnya, takarannya, atau ukuran ukuran yang lainnya, maka tidaklah sah jual beli yang menimbulkan keraguan salah satu pihak. $^{12}$

Jadi dari uraian di atas diketahui bahwasanya jual beli itu memiliki syarat dan ketentuan yang harus diikuti agar tidak terjadi sesuatu yang tidak dibenarkan oleh Allah swt. Mencapai keridhaan Allah dalam jual beli adalah suatu keharusan bagi seluruh ummat Islam.

\section{Jual beli yang dilarang dan batal hukumnya}

Ada beberapa jual beli yang dilarang dan batal hukumnya ${ }^{13}$ yaitu:

a. Barang yang dihukumkan najis oleh agama, seperti anjing, babi, berhala, bangkai dan khamar.

b. Jual beli sperma (mani) hewan, seperti mengawinkan seekor domba jantan dengan betina, agar dapat memperoleh turunan, jual beli ini haram hukumnya.

c. Jual beli anak binatang yang masih berada dalam perut induknya, jual beli seperti ini dilarang, karena barangnya belum ada dan tidak tampak juga.

d. Jual beli dengan muhakallah, haqalah mempunyai arti tanah, sawah dan kebun, maksud muhaqallah disini ialah menjual tanam tanaman yang masih di larang atau disawah, hal ini dilarang dalam agama, sebab ada persangkaan riba didalamnya.

e. Jual beli dengan mukhadharah, yaitu menjual buah buahan yang belum pantas untuk dipanen, seperti menjual rambutan yang masih hijau, mangga yang masih kecil-kecil dan yang lainnya. Hal ini dilarang karena barang tersebut masih samar, dalam artian mungkin saja buah 
tersebut jatuh ditiup angin kencang atau yang lainnya, sebelum diambil oleh sipembelinya.

f. Jual beli dengan muammassab, yaitu jual beli secara sentuh menyentuh, misalkan seseorang menyentuh sehelai kain dengan tangannya di waktu malam atau siang hari, maka orang yang menyentuh berarti telah membeli kain tersebut. Hal ini dilarang karena mengandung tipuan dan kemungkinan akan menimbulkan kerugian bagi salah satu pihak.

g. Jual beli dengan munahadzab, yaitu jual beli secara lempar melempar, seperti seseorang berkata; "lemparkanlah kepadaku apa yang ada padamu, nanti kulemparkan pula kepadamu apa yang ada padaku setelah terjadi lempar melempar, maka tidak ada ijab dan kabul.

h. Jual beli dengan muzahanab, yaitu menjual buah yang basah dan buah yang kering, seperti menjual padi kering dengan bayaran padi basah, sedangkan ukurannya dengan dikilo, maka akan merugikan pemilik padi kering.

i. Menentukan dua harga untuk satu barang yang diperjualbelikan menurut Syafi'I penjualan seperti ini mengandung dua arti, yang pertama seperti seseorang berkata; “kujual buku ini seharga \$10 denan tunai atau \$15 dengan cara hutang. Arti kedua ialah seperti seseorang berkata; "aku jual buku ini padamu dengan syarat kamu harus menjual tasmu padaku"

j. Jual beli gharar, yaitu jual beli yang samar sehingga kemungkinan adanya penipuan, seperti penjualan ikan yang masih di kolam atau menjual kacang tanah yang atasnya keliatan bagus tapi dibawahnya jelek.

k. Jual beli dengan mengecualikan sebagian dari benda yang dijual, seperti seseorang menjual sesuatu dari benda itu ada yang dikecualikan salah satu bagiannya, misalnya A menjual pohon pohonan yang ada dikebunnya, kecuali pohon pisang, maka jual beli ini sah, sebab yang dikecualikannya jelas. Tapi bila yang dikecualikannya tidak jelas(majbul), maka jual beli tersebut batal.

Larangan menjual makanan sehingga dua kali takar, hal ini menunjukkan kurang saling mempercayainya antara penjual dan pembeli, jumhur ulama berpendapat bahwa seseorang yang membeli sesuatu dengan 
takaran dan telah diterimanya, kemudian ia menjual kembali, maka ia tidak boleh menyerahkan kepada pembeli kedua dengan takaran yang pertama, sehingga ia harus menakarnya lagi untu pembeli yang kedua itu. Rasulullah Saw melarang jual beli makanan yang dua kali takar, dengan takaran penjual dengan takaran pembeli.

\section{METODE PENELITIAN}

Jenis penelitian ini adalah penelitian kualitatif yaitu proses penelitian untuk menghasilkan data berupa penjelasan, baik tertulis maupun tidak tertulis dengan orang-orang yang diteliti. Adapun yang diteliti oleh peneliti adalah 16 penjual dan 7 pembeli. Sumber data adalah subjek darimana dan dapat diperoleh. Penelitian menggunakan sumber data primer dan sekunder, adapun yang dimaksud data primer dan sekunder. Adapun teknik pengumpulan data dalam penelitian ini adalah Wawancara, observasi, dan studi kepustakaan.

\section{HASIL PENELITIAN DAN PEMBAHASAN}

Hasil penelitian menunjukkan bahwa jual beli ini berada di tengah-tengah perkampungan, dimana penjual membuka warung di depan rumahnya, dan pembelinya biasanya adalah tetangga-tetangganya. Dalam jual beli ini pedagang rumahan biasanya membeli barang ke pasar dan menjual di depan rumahnya. Dalam pedagang rumahan ini ada dua kategori yaitu yang pertama berdagang barang kemasan dari pabrik seperti masako, potato, bango dan lain-lain. Dan yang kedua berdagang barang non pabrik seperti gula pasir kiloan, minyak melinda, sayur-sayuran dan lain-lain. Namun yang diteliti adalah pedagang rumahan yang pada umumnya menjual barang-barang pabrik akan tetapi menjual sebagian barang kiloan juga. Banyak juga pedagang-pedagang makanan ringan yang juga menjual minyak goreng kiloan dan juga gula pasir kiloan. Karena pada umumnya menjual makanan ringan jadi tidak terlalu memerlukan timbangan, namun sebagai tambahan dagangannya pedagang menjual gula pasir dan minyak goreng tersebut banyak yang tidak menggunakan timbangan hanya saja mengukur dengan plastik.

Berdasarkan hasil penelitian ditemukan secara garis besar praktek jual beli yang dilakukan masyarakat kelurahan wek-I Kecamatan Padangsidimpuan Utara ini adalah sistem jual beli dengan cara ifsad karena di saat pembeli 
244 | TAZKIR: Jurnal Penelitian Ilmu-ilmu Sosial dan Keislaman

Vol. 04 No. 2 Desember 2018

membeli barang dan ternyata barangnya tidak sesuai dengan akad karena timbangannya tidak sesuai.

1. Pemahaman masyarakat terhadap jual beli dengan cara ifsad di Kelurahan Wek-I Kecamatan Padangsidimpuan Utara tidak mengetahui apa itu ifsad, namun mereka mengetahui bahwa diwarung-warung rumahan sering terjadi pengurangan timbangan dalam suatu barang. Masyarakat mengetahui bahwa pengurangan timbangan dalam jual beli sudah melanggar hukum islam.

2. Metode/ cara pelaksanaan jual beli barang dengan cara ifsad di Kelurahan Wek-I Kecamatan Padangsidimpuan Utara dilakukan dengan cara membungkus terlebih dahulu, masing-masing barang yang akan dijual seperti minyak goreng dan gula pasir dengan ukuran berpatokan dengan plastik yang berukuran, misalnya seperti membungkus minyak goreng dan gula pasir ke dalam plastik yang berukuran $1 / 4 \mathrm{~kg}$ dengan banyak bungkusan, ketika pembeli datang barang tersebut langsung diberi dan tidak ditimbang kembali dihadapan pembeli.

3. Alasan-alasan penjual dan pembeli dalam melakukan jual beli dengan cara ifsad di Kelurahan Wek-I Kecamatan Padangsidimpuan Utara adalah Penjual menjual dengan cara ifsad di Kelurahan Wek-I Kecamatan Padangsidimpuan Utara karena penjual ingin memperoleh untung lebih banyak karena sedikitnya untung yang diperoleh penjual dan ada juga penjual yang tidak mau membeli timbangan karena akan membutuhkan modal lagi untuk membeli timbangan.

\section{PENUTUP}

Dari temuan penelitian diketahui bahwa banyak terjadi kecurangan dalam pelaksanaan jual beli di masyarakat Wek-I Kota Padangsidimpuan, hal ini diketahui dari barang yang telah dibeli, tidak sesuai dengan apa yang dibeli dan timbangan yang kurang dari yang seharusnya. Dalam melakukan jual beli masyarakat di Keluarahan Wek-I Kecamatan Padangsidimpuan Utara melakukan dengan cara ifsad. Cara yang dilakukannya adalah dengan membungkus apa yang dibeli oleh pembeli terlebih dahulu. Jual beli ifsad dilakukan berdasarkan pada alasan bahwa para penjual inginkan keuntungan yang lebih besar dari biasanya. Apapun alasannya jual beli harus dilakukan dengan jujur agar pembeli tidak dirugikan, dan penjual juga mendapatkan pahala atas penjualan yang dilakukannnya. Apabila terjadi kecurangan dan 
kebohongan dalam penjualan yang dilakukan maka para penjual tersebut sudah dhzalim kepada penjual, dan akan mendapatkan hukuman dari Allah swt.

Dari hasil penelitian maka diberikan saran kepada penjual dan pembeli beberapa hal:

1. Kepada penjual peneliti menyarankan kepada penjual minyak goreng dan gula pasir agar tidak membungkus terlebih dahulu barang yang dijual agar tidak menimbulkan keraguan kepada penjual, jika memang untuk memudahkan cara penjualannya maka penjual harus menimbang minyak goreng dan gula pasir dengan timbangan yang sesuai dan tidak mematokkan plastik saja agar tidak merugikan pembeli dan tidak menyimpang dari syariat islam.

2. Kepada pembeli peneliti menyarankan agar membeli barang juga harus meminta penunjukan kepada penjual, dan meminta penimbangan kembali disaat membeli barang diwarung makanan yang menjual minyak goring dan gula pasir agar tidak ada keraguan dan peluang untuk penjual mengurangi ukuran barang dari yang seharusnya. 
246 | TAZKIR: Jurnal Penelitian Ilmu-ilmu Sosial dan Keislaman

Vol. 04 No. 2 Desember 2018

\section{DARTAR PUSTAKA}

Ahmad Nizar Rangkuti, Metode Penelitian Pendidikan, Bandung: Cita Pustaka Media, 2014.

Dwi Suwiknyo, Ayat-Ayat Ekonomi Islam, Yogyakarta: Pustaka Pelajar, 2010.

Departemen Agama, Al-Quran dan Terjemahannya, jakarta: Wisma Haji Tugu, 2017.

Dedy Mulyana, Metode Penelitian Kualitatif, Bandung: PT. Remaja Rosdakarya, 2002.

Husein Umar, Penelitian dan Tesis Bisnis, Jakarta: PT. Rajagrafindo Persada, 2013.

Hendi Suhendi, Figh Muamalah, Jakarta: PT. Rajagrafindo Persada, 2014.

Ika Yunia Fauzia, Etika Bisnis Dalam Islam, Jakarta: PT. Fajar Interpratama Mandiri, 2013.

Lexy J. Moleong, Metode Penelitian Kualitatif, Bandung: Remaja Rosdakarya, 2004.

Muhammad Djakfar, Hukum Bisnis, Yogyakarta: PT LKIS Prionting Cemerlang, 2009.

Muhammad Nasir, Metode Penelitian, Jakarta: Ghalia Indonesia, 1998.

Nasrun Haroen, Figh Muamalah, Jakarta: Gaya Media Pratama, 2000.

Peter Mahmud Marzuki, Penelitian Hukum, Jakarta Kencana, 2009.

Suharsimi Arikunto, Prosedur Penelitian suatu Pendekatan Praktek, Jakarta: PT. Rineka Cipta, 2002.

Soejono Soekarto, Pengantar Penelitian Hukum, Jakarta: Penerbit Universitas Press, 1986.

Teungku Muhammad Hasbi Ash Shiddieqy, Pengantar Hukum Islam, Semarang: PT. Pustaka Rizki Putra, 1987.

Zulham, Hukum Perlindungan Konsumen, Jakarta: Prenadamedia Group, 2013. 